\title{
Water Quality, Essential Condition Sustaining the Health, Production and Reproduction in Cattle. A Review
}

\author{
Cristina EL MAHDY ${ }^{1 *}$, Anca BOARU ${ }^{1}$, Silvana POPESCU ${ }^{2}$, Cristin BORDA ${ }^{2}$ \\ ${ }^{1}$ Faculty of Animal Husbandry and Biotechnologies,University of Agricultural Sciences and Veterinary \\ Medicine, Calea Mănăștur street 3-5, Cluj-Napoca, România \\ ${ }^{2}$ Faculty of Veterinary Medicine, University of Agricultural Sciences and Veterinary Medicine, Calea \\ Mănăştur street 3-5, Cluj-Napoca România \\ * corresponding author: cristina.hegedus@usamvcluj.ro
}

Bulletin UASVM Animal Science and Biotechnologies 73(2)/ 2016

Print ISSN 1843-5262; Electronic ISSN 1843-536X

DOI:10.15835/buasvmcn-asb: 12156

\begin{abstract}
The main component of the body: the water, alongside with many function which it has represents a constituent in the diet of animal. There are many and various factors that influence the daily water requirements of animals: some dependent on animal, and others dependent on the environment. The water quality administered to livestock must meet the requirements for potability, prerequisite to maintaining the health, externalization full productive potential and sustaining breeding. Knowing the importance of water quality consists in the negative action which can exert on the body to exceeding certain thresholds translated through: reducing water consumption simultaneously with the decrease of milk production, decreased feed conversion rate and average daily gain, degradation of health status by reducing the local resistance, decrease overall body resistance, metabolic, digestive, skeletal disorders and impaired reproduction sphere translated through: decreasing fertility, abortions; elements interfering with the absorption of other essential water body, producing chronic or acute poisoning. The water composition plays essential role depending on which is supplemented or not as the case in quantity of the macro and trace minerals from feeding stuff according to the synergism or antagonism action between the minerals present.
\end{abstract}

Keywords: cattle, parameters, water, quality

\section{THE IMPORTANCE OF WATER FOR ANIMAL BODY}

In the organism, water has structural role, being the main component of the body; intervenes in all metabolic processes; represents the substrate of all biochemical reactions in the body (hydrolysis, redox, hydration, imbibition) and is a source of calcium, magnesium, sodium, potassium and other useful substances to the body, but sometimes and for unwanted elements (toxic substances, pathogenic agents) (Murphy, 1992), controls acidity levels. Water is the main solvent of organic substances intra- and extracellular (Umara, 2014), contributes to the maintenance homeostasis, is essential for various processes, such as absorption, transport, diffusion, osmosis, excretion, carrier of substances and heat energy in the body, nutrition roll, antitoxic, participates in thermoregulation (Man, 1989; Man et al., 2002).

Why is the water important for the body? Without food, but with access to the water, animals may lose the greatest amount of glycogen, all lipid reserves, $50 \%$ from proteins and up to $40 \%$ of body weight, in which case survival in the absence of feed can reach at 40 days and the recovery is still possible by re-introducing feed (Teușdea, 1996).

Without water and administering a dry feed, the animals lose in $2-3$ days $10 \%$ of body 
weight concomitantly with occurrence of serious disorders, and, a loss of $20-30 \%$ by weight dependent on the species and age it is lethal (Man, 1986).

Water losses that occurring from animal organism is caused by physiological processes: urine, particularly important not only point of view quantitatively, but also because it is the adjustable element and most mobile in fluid losses from the body; feces, but in this way only a small part of the water from the body is lost (Looper, 2012).

Another way to losing water from body consists in evaporation that takes place continuously at skin and lung level, even when the atmospheric air temperature is low (www.nap.edu, 2001). The animals transpiration has a content of 95 to $99.5 \%$ water, so it is hypotonic (Popescu et al., 1981; Lixandru, 2011).

Animal water requirement can be ensured only by drinking water intake. Very low quantities of water results from the water of constitution of foods and fodder preparation, endogenous water or metabolic which cannot satisfy the water demand/animal head (Podar et al., 2005). Since the water of constitution of the feed is extremely variable and endogenous water is not adjustable because the metabolism is dictated by energy needs and not by the need of water, it results that the only adjustable part is represented by direct consumption of water. Ingestion of water is determined by the thirst that appears at variations of $0.5-2 \%$ of the total water lost $(1.5 \%$ loss and $0.8 \%$ of the extracellular cell sector), or the osmolarity of body fluids (El Mahdy, 2013).

\section{FACTORS THAT INFLUENCE WATER CONSUMPTION IN ANIMALS}

Numerous and various factors influencing requirement daily water in dairy cows; some of them depend on the animal, others of environment (El Mahdy, 2013).

Between factors dependence by animals that influences the water consumption are listed: age, body weight, physiological stage, the direction of exploitation and productive level, individual behavior (Drăghici, 1996; Drăghici, 2001); pregnancy, activity (Gherman, 2008), stress levels, health status (El Mahdy, 2013); and of those dependent on the environment: type of diet, feed intake, dry matter content of ration, total dry matter intake, structure and chemical composition of the ration ingested (proteins, carbohydrates, minerals, food additives), level and type of feeding (concentrate, voluminous), presentation of food, salinity and the amount of water from the composition of the feed, season (Schlink et al., 2010); environmental temperature (Lardy et al., 2008) and humidity (Curran, 2014), type of watering (Grant, 1993).

The influence of nutrition on water consumption in animals. There is a strong positive relationship between the content of dry matter from feed and water intake requirements, dry matter content of the diet being one of the primary factors affecting the water needs of the animals (Şara, 2007) .In the case of the dry matter of the feed drops from 50 to $30 \%$, there is a decrease in consumption of water. Stockdale et al. (1983) show a decrease in water intake in dairy cows at pasture, due to higher water content found in the grass. In this case the cows drank only $38 \%$ of the amount of water / head cow feed.

Feed with a high content in salt, sodium bicarbonate, or protein, leading to stimulation of water consumption; (Murphy,1992; Holter et al., 1992).

In cattle rations with high content of minerals, raises the amount of water ingested; leguminous hay require more water than gramineae hay. The same increase is noticed in the administration of whey, rich in minerals (Man, 1989).

For dairy cows daily amount of water ingested expressed at UVM $(500 \mathrm{Kg})$ has variables limits: 32-121 l/ UVM dairy cows and 27-70 l / UAM at young cattle, after Man (1989). Depending on the ratio water/feed, water consumption is situated on average between 4 to $4.5 \mathrm{l} / \mathrm{kg}$ dry matter intake in maintenance conditions to $15^{\circ} \mathrm{C}$. Water consumption is $4 \mathrm{l} / \mathrm{kg}$ dry matter if the ration is dried and $5 \mathrm{l} / \mathrm{kg}$ dry matter if the ration is composed by forage rich in water (Man, 2007). After NRC, 2001 the quantity of water/Kg dry matter feed intake depend on temperature is as follows: $35^{\circ} \mathrm{C}: 8-15 \mathrm{l} ; 25-35^{\circ} \mathrm{C}: 4-10 \mathrm{l} ; 15-25^{\circ} \mathrm{C}$ $3-5 \mathrm{l} ;-5-15^{\circ} \mathrm{C} 2-4 ;<-5^{\circ} \mathrm{C} 2-3 \mathrm{l}$ water / kg dry matter feed intake.

Low temperature of air can affect water intake by reducing consumption, which in turn influences reducing water flow through the bladder and kidneys which leads to the formation of kidney stones (Lardy, 2008). After the same author, kidney stones occur under the influence of any factors that 
lead to decreased water consumption. Quantities of water less than the daily requirement entails: less intake of feed, decrease in production of milk, constipation, weakness, increases in quantity of urea in urine and bad smell, incomplete digestion.

\section{Water quality}

Beede $(1994,2005)$ considers that water is an important component in animal diet, alongside protein, carbohydrates, lipids (fat), vitamins and minerals (Harper, 2012).

According to other experts in the field, the water is the most essential nutrient for dairy cow (www.holsteinfoundation.org ${ }_{2}$ ), and this is due to the fact that the nutrients present in the feed come with a contribution of $12 \%$ while water contributes with 88\%, after Pierce (2011).

After air, water is the factor with the greatest daily requirements in dairy cows (Prairie, 2014), therefore water quality must be known. Consumption of water with modified properties: organoleptic, physical, chemical, biological or microbiological can create problems, as well as, the presence in excess of some mineral in water that constitute an risk factor on status of health and a major impediment on productive and reproductive performance (Drăghici, 2001).

The presence of minerals from water contribute at daily intake of mineral concomitant with their decreasing from feed administrated to cattle (Elrod, 2013), because can interfere with bioavailability of other micro or macro minerals by synergistic or antagonism action if the quantity found in water overlaps those in feed producing chronic or acute poisoning (Man, 2002; 2007).

\section{ORGANOLEPTIC PROPERTIES}

It refers to smell and taste of water. The water smell is influenced by the presence into the water of dissolved from certain substances and odorous gases or, there the possibility like the water to be contaminated and in this case, the water borrow the smell of polluting substances (Teuşdea, 2003). The animals behavior related to water consumption with modified smell varies according with species, and dairy cow refuse or consume small quantity of water (Man, 2002; Man, 2007; Beede, 2006).The main cause of smell of ammonia consists in by permeation of soil and decomposition of liquid manure in water (www.water-research.net). Cattle will not reduce consumption of contaminated water until manure exceeds $0.25 \%$ in the water (Braul et al., 2001). The presence of humic compounds or decomposition of organic matter imprint the water marsh smell (Ştețca et al., 2008). The rotten egg smell is give by hydrogen sulphide which is produced by some gases dissolved or transformation of mineral substances, or is the results of decomposition of organic matter (Popescu, 2010). Large amounts of hydrogen sulphide from water can produce polioencephalomalacia (polio or PEM) it was not taken into account the amount from feed composition (Haydock, 2003; Crawford, 2012). Fishy smell can be caused by naturally organic material existing in the earth like barium or cadmium metals (www.epa.go), and the contact of water with products or oil residues - oil odor (Swistock et al., 2012). One of the problem that worries is the growth of algae in water that alter the smell but can produce poisoning at animals that consumes this water, too (Salverson , 2012). Green algae blooms can produce a grassy or fishy odor (Hoehn, 2002). Aromatic smells are produced of diatoms and in particular by Asterionella formosa or sickening smell of fish if they are in big quantity (Hegedűs, 2006). Big quantity by protozoa Cryptomonas sp., Mallomonas borrow a strong smell of violets or fishy (Ionescu,1980), Synura: cucumber, bitter taste (Hoen, 2002), Dynobrion, Peridinium: fishy, Uroglena: fishy, oily (Hubbard, 1907). The decomposition of the blue-green algae leads to change of smell (www.ediblegeography. com,) especially Anabaena who changes the smell of water comparable to that grass freshly cut often accompanied by a musty smell.

The taste of water is given by present of mineral salts, dissolved gases in report with the presence of oxygen and carbon dioxide, temperature. The taste of water can be modified due to certain mineral found in excess (Kot-Wasik, 2007).

Usually the taste of water is influenced by chemical composition of soil over which water crosses , but can be the results of some antropic activities and biological processes which occurring in water (El Mahdy, 2013). The particularities of taste are due to presence in water of some big quantity of sodium chlorid (over $350 \mathrm{mg} / \mathrm{dm}^{3}$ ), magnesium salts (sulfate or chloride) give bitter taste; sulfates imprint brackish-bitter taste; aluminum give earth taste of the water, the iron, manganese: 
mettalic taste (McFarland et al., 2004), zinc salts - astringent taste, calcium sulfate - sweetish taste, sour taste given by bichromate or ferric chloride (Man, 1989, Teușdea, 1996), humic substances: bitter taste (www.gov.ns.ca,).

The modified taste decrease the palatability, concomitant with intake of some low quantity of water with repercussions on milk production, deteriorating the status of health and decreasing absortion of other essential minerals for organism (www.milkproduction.com,).

\section{Physical properties}

Water temperature, is an essential physical parameter which varies depending on source. Usually underground water has low temperature but constant (www.lenntech.com,). Maintaining this temperature is beneficial for cows (Braul et al., 2001). The temperature of groundwater bodies do not present wide variations during a year, this parameter being influenced by the depth and air temperature: $4-8 \mathrm{~m}-5-15^{\circ} \mathrm{C}, 8-12 \mathrm{~m}-7-11^{\circ} \mathrm{C}$, over $12 \mathrm{~m}-8-9^{\circ} \mathrm{C}$ (Popescu etal., 1985); between 15-25 m the temperature is equal to the temperature of the multiannual average from the surface, and under below this depth the temperature are found under the action of geothermal gradient (Scrădeanu et al., 2014). The temperature can be an indicator of contamination when the fluctuations are noticed, case in which it is supposed the existence of contact with the outside (El Mahdy, 2013). In return, the value of temperature to the surface waters are influenced by atmospheric temperature, reason for that, this is oscillating (Man, 1989).In our area, on summer, the surface water depend by features: flowing water or stagnant water, and may reach at 20-25 degree, and, in winter time in particular the waters with small debit, stagnant, the water freezes (Drăghici, 2001).

High temperature of water are translated through: failure to satisfy the thirst sensation because it is devoid of $\mathrm{CO}_{2}$ (Gligor et al., 1971), unpleasant taste, hamper the processes of thermoregulation causing decreasing milk productions (Man, 2007).

For dairy cow optimum temperature of watering is between $15-17^{\circ} \mathrm{C}$ (www. milkproduction.com,), fact reported by Andersson M. (1985). Following the quantity of water ingested by cows, intake is approached at temperatures of 10- $17^{\circ} \mathrm{C}: 76.6-76.0 \mathrm{l} / \mathrm{cap}$, milk production being maximum at water intake with temperature by $17^{\circ} \mathrm{C}$. Other studies indicate that water intake between 7 and $16^{\circ} \mathrm{C}$ reduces tympanic temperature and respiratory frequency in dairy cows (González Pereyra et al., 2010).

Consumption of water with low temperature leads to gastric and intestinal disorders, congestion and abortion at pregnant females found in the last period of gestation (El Mahdy, 2013). At low temperatures of the air it is preferred administrating some warmish water (Ensley, 2000).

\section{Chemical properties}

Knowledge of the chemical parameters of water are important especially when the water has in composition high quantity of certain elements which may overlap over minerals administrated in feed (Beede, 2006). The same author suggests a minimum of parameters in assessing water quality administered to the dairy cows: total dissolved solids (TSD), sodium, calcium, magnesium, chloride, sulfate, $\mathrm{pH}$, nitrate, iron, manganese, copper, hardness, conductivity.

\section{Total dissolved solids (TSD)}

Salinity of water depends by quantity of salts: sodium, chloride, bicarbonate, sulfate, calcium, magnesium and smaller quantity of silica, iron, nitrate, strontium, potassium, carbonate, phosphorus, boron and fluoride (profsite.um.ac. ir). TSD represents in the same time a guide of waters quality (Broadwater, 2007), an preindicator of poor quality water (Adams et al., 2009). Two water sources may have similar salinity levels but different effects, depending on the salts present (Higgins et al., 2008). Sodium chloride it is first parameter taken into account when TSD values are high but the action is less harmful on heath than the sulfates combined with magnesium and/or sodium (Linn, 2008; Lardy et al., 2008) and of these magnesium chloride has action much damaging than calcium salts or sodium (Griffith, 1998).

After Patterson et al., (2003) water with high level in salt content can compromise performance and health of cattle by: reducing the water and feed intake; toxic levels of sulfur ingestion; or can induce trace mineral deficiencies.

In National Research Council (N.R.C.),(2001) (profsite.um.ac.ir) it is specified that, the water 
with salinity under 1000 ppm is consider safe, higher values having negative effects on health status and animal products as fallow: values between 1.000-2.999 ppm have moderate action through installation of temporary diarrhea at animals who are not accustomed with quality of the water source. TDS between 3.000-4.999 ppm/ $\mathrm{dm}^{3}$ reduce water consumption and sometime can install moderate diarrhea. Several studies have shown that TDS between 4.000 to 5.000 ppm negatively affect daily average gain, decrease milk production in lactating cows which cause a reduction in weights at calves at weaning (Dyer, 2012). If the salinity is high (around EC 4000 $\mu \mathrm{S} / \mathrm{cm}$ ) but chloride levels are normal, shall be analyzed other salts that contribute to raising TSD values (Curran, 2014).

There is a warning in particular for lactating cows as well as gestating, to avoid the water whose content in TDS is between 5.000-6.000 ppm, because cause diarrhea and in this case is compulsory determination of sulfates from water (Tennis, 2007). When TSD value is between 4.400- $6.000 \mathrm{ppm}$ cattle has lower weight gains than cattle drinking normal water (TDS $=1$ $300 \mathrm{ppm}$ ), only in conditions where, content of energy from feeds is low during heat stress. In other circumstances: intake of feeds with high energy even in cold environmental it does not have negative repercussions (Looper et al., 2002). Over $7.000 \mathrm{ppm} / \mathrm{dm}^{3}$, the water is saline, which affect the intake of water with repercussions on milk production, who decrease and in the same time affect the health of animals. Gadberry (www. uaex.edu), specify the fact that, the consumption of water with value of TSD between 7.000 and $10.000 \mathrm{ppm}$ is sure for dry beef cows in condition of minimal environmental stress. Waldner et al., (2012) considers that the water with a content higher than $10.000 \mathrm{ppm}$ is unsafe and should not be administrate to animals.

Water $p H$. The livestock can support variations of $\mathrm{pH}$ between 6.5-8.5 unit.pH (Curran et al., 2007). The dairy cow prefers water with pH between 6.0-8.0 unit. pH (Olkowski, 2009). Exceeding this threshold, the water has lye taste, and under 6.5 unit $\mathrm{pH}$ the taste of water is acidulous prickly due to of humic acids, mineral and especially due to the presence of carbon dioxide in high quantity (Man, 1989, 2007; Drăghici, 2001; Popescu,
2010). Usually the underground water has alkaline reaction (Lixandru, 2011). Unfavorable action of low or high $\mathrm{pH}$ were associated with decreasing milk production concomitant with fat content, decreased average daily gain and increase the susceptibility at infection, installation of some metabolic disorder and reducing fertility (Adams et al., 2009). At ruminants the consumption of water under 5.5 unit $\mathrm{pH}$ produce metabolic acidosis (Grant, 1993) but, after Ishle V. (www. didattica.unitus.it) seems to be only a contributory factor, alongside intake and environmental factors.

Alkaline water with $\mathrm{pH}$ higher than 8.5 unit $\mathrm{pH}$ lead to heightened risk of metabolic alkalosis occurrence (Swistock, 2012), B-vitamin deficiencies, and symptoms similar to mild acidosis (Grant, 1993). Other authors such as Bagley et al., (1997), Man $(1989,2002)$ indicates other negative repercussions of water consumption with high $\mathrm{pH}$ : digestive disorder, diarrhea, poor feed conversion and reduced water/feed intake. When cows drink alkaline water, rich diet in alfalfa, buffers and minerals, they are more likely to the occurrence of mild alkalosis (Grant, 1993).

Dependent of water $\mathrm{pH}$, the effect can be corrosive on water supply system influencing at the same time the effectiveness of chlorination (Hersom et al., 2008)

Totall hardness is given by all calcium and magnesium salts that are found in water and is considered overall indicator of water mineralization (Straus, 1981). Depending on salts concentration from water (carbonate, bicarbonate, sulfates, silica, nitrate, phosphates, by calcium and magnesium, along with potassium, sodium, iron, manganese, etc., the waters can have variable hardness, depending on which can divided in soft water $\left(0-6^{0}\right)$, semi hard $\left(6-12^{0}\right)$, hard water $(12$ $18^{\circ}$ ) and very hard water (over $18^{\circ}$ ) (www.who. int,).

Consuming the water whose hardness is too high or too low represents an permanently topic for research, controversially in terms of action and the effect on health condition of animals (Drăghici, 2001). The high hardness can cause altering of health condition by the presence of renal calculus, gastric disorders, chronic catarrh of the digestive mucosa and even methaemoglobinaemia especially when animals accustomed to a type of water are forced to consume water with high 
hardness (El Mahdy, 2013). Lardy (2008) points out that the: consumption of water with high hardness is not a factor in their appearance, but affects water palatability.

On other hand, hard water caused by high calcium levels can influence the incidence of milk fever in a dairy herd (www2.gnb.ca).

Opposed these reactions, was notice that the water with low hardness is favorable, positively influencing the milk production (Popescu et al.,1981;1985).

When hardness equals alkalinity, salts of calcium and magnesium combined with carbonates and bicarbonates are indicated. When alkalinity is less than hardness, salts of calcium and magnesium are more likely to be sulfates instead of carbonates (Tennis ,1997) and if the alkalinity exceeds the hardness indicate the presence of sodium and potassium salts in addition to calcium and magnesium (German et al., 2008).

Calcium. For livestock, the calcium from water not represent risk of toxicity, but if the feed contained high amount of calcium, contribution of calcium from water becomes significant (Dumitru, 1996), the effect on status of health by most of the time being associate with metabolic and skeletal disorder: ankylosis spine, degenerative osteoarthritis and in certain case, the heart function can be compromised or in advanced cases or extremely, the heart falls (Olkowski, 2009).

The metabolic disorders consist in interfering with bio availability of other macro and micro essential minerals: P, Zn Mn (www.milkproduction. com). By point of view of feed, calcium in excessive amount reduce nutrient takeover and especially affect fats digestibility (Milos et al., 1980). The absorption of selenium is impairs by higher amount of calcium, over $12.5 \mathrm{~g} \mathrm{Ca} / \mathrm{Kg}$ feed, reason for that must take account by calcium existing in drinking water (Higgins, 2008). The amount of calcium from water can reach at $1.000 \mathrm{mg} \mathrm{Ca}^{2+} / \mathrm{dm}^{3}$ but, if the water contains also much magnesium too, the quantity decreases at $700 \mathrm{mg} \mathrm{Ca}{ }^{2+} / \mathrm{dm}^{3}$ (Wright , 2003; 2012).

Sulfates are essential for animal nutrition, but large amount of sulfates prints brackish-bitter taste (Provin et al., 2002). The taste of water is changed at different concentrations of the salts of sulfates: $250-500 \mathrm{mg} / \mathrm{dm}^{3}$ sodium sulfate, 250 -
$900 \mathrm{mg} / \mathrm{dm}^{3}$ calcium sulfate, $400-600 \mathrm{mg} / \mathrm{dm}^{3}$ magnesium sulfate (www.who.int,).

Common forms of sulfate in water are calcium, iron, magnesium and sodium salts.

All are laxative, but sodium sulfate is the most potent (Schroeder, 2016).

Along with other salts: chlorides, nitrates, phosphates, bicarbonates of sodium, potassium, calcium, magnesium, iron and manganese, the sulfates participate in increasing the total salinity of the water (El Mahdy, 2013). Although that the sulfate modify the water taste, cattle adapts and consume such kind of water, but as for the other species, the large amounts of sulfates contained in the water along with the amount found in feed are associated with gastrointestinal disorders, dyspepsia, gastroenteritis, diarrhea, under the action of sodium sulfate (laxative), which is also a substrate for the production of hydrogen sulfide, a lethal neurotoxin compound for cattle (Man, 1989).

Over $1.200 \mathrm{ppm}$ sulfates present in drinking water, compromise production performance of fresh dairy cows because of reducing the feed intake (Beede, 2005).

Average daily gain is reduced to the cows and calves, if the water has concentrations higher of $1.300 \mathrm{mg}$ sulfate $/ \mathrm{dm}^{3}$ water, and are not affected by amounts for up to $630 \mathrm{mg} / \mathrm{dm}^{3}$ (www.ehsdata. com,). Calves are more sensitive than adult animals and suffer from chronic diarrhea and electrolyte imbalance at values of sulfates between 350-600 ppm (Griffith, 1998).

Cattle consuming water with 2.000-2.500 ppm sulfates show diarrhea initially, but appear to become resistant to the laxative effect. Drinking water containing $2.814 \mathrm{ppm}$ sulfate increase the methemoglobin concentration and renal function are significantly altered after Ensley (2000) and Tennis (2007) considers that the values of sulfates greater than $4.000 \mathrm{mg} / \mathrm{dm}^{3}$ are dangerous for health.

Adverse effects by manifestations of polioencephalomalacia (PEM, thiamin deficiency) in ruminants were signaled at values greater than 3.000 ppm (Harty, 2012), a disorder of nervous system associated with the existence of large amounts of sodium sulfate.

The adverse action is mainly associated with presence of sulfate in a ratio, higher than that sodium, which consists in: poor hair coat, reduced 
growth rate, weight loss, decrease the fertility, low conception and low rates of ovulation at cow, reduction in semen quality at bulls (www. agriculture.gov.sk.ca,). The same effect was observed in the case of meat calves by cumulative action of sulfates from feed and those present in the water composition (Looper et al., 2002).

High levels of sulfate were correlated with reducing the percentage of milk fat and interfering with the intestinal absorption of other minerals such as copper (Irsik, 2012), increased requirements for selenium, vitamin E (Linn et al., 2010; Swistock, 2016).

Health problems can occur due to immune system depression, but also, affect the reproduction sphere by reducing the availability of essential micro minerals: zinc, manganese (http://www.spiplastics.com,).Other negative effects noticed consist in: increased incidences of retained placenta and abomasal displacement (Beede, 2006).

Sulfates values in drinking water for cattle is dependent on the age, the maximum permissible value from calves being $500 \mathrm{ppm}$ and, for adult cattle, meat breeds, $1.000 \mathrm{ppm}$ (Poppenga et al., 2014), but after Beede, (2006) is very important that both: sulfates and chloride do not exceed $1.000 \mathrm{ppm}$.

Iron sulfate has been reported to be the most potent depressor of water intake compared with other sulfate forms (Looper et al., 2002).

\section{Chlorides}

Chlorides from water can have telluric origin, in which case the values obtained after performance the analyzes are relatively constant, but, dry periods entail an increase in the values of this parameter in which case is not suspected the existence of a source of contamination (El Mahdy, 2013) or, may get into surface water from several sources like: wastewater from industries and municipalities, effluent wastewater from water softening, road salting, agricultural runoff and produced water from oil and gas wells (Iowa Department of Natural Resources DNR 2009).

Chlorides above $250 \mathrm{mg} / \mathrm{dm}^{3}$ can imprint a salty taste to water which could result in reduced water intake and milk production. High amount of chlorides present in water should be considered when formulating diets, to prevent the excess which could be detrimental to rumen function (Swistock, 2016).

Sodium chloride poisonings in cattle are a result of administering of a feeding-stuff as rich in salt. Direct consumption of salt and low potassium quantity in feed, changes occurred in the water palatability, high consumption of water with a high concentration of sodium chloride, insufficient watering front, whose manifestations consist of occurrence of toxic encephalosis: hyperexcitability (tremor, muscle cramps, colic), followed by inhibition (amaurosis, paraparesis) (www.aidvet.com,).

Episodes of poisoning after consumption of water with high amount of sodium chloride in adult cattle is manifested by gastrointestinal irritation, accompanied by emesis, diarrhea, the presence of mucoid faeces, thirst, salivation (Man, 2007), animals appear unwell, lose appetite and are reluctant to drink water, initially increase the urination followed by small amounts but concentrated, nasal discharge, abdominal pain, animals prefers to stay lying down (Curan, 2014) and nervous signs such as: star gazing, tremors, blindness, circling, walking backwards, head pressing, wobbly in the legs; knuckling at the fetlocks and convulsions) and even death (Bradford, 2014)

Sodium by itself, poses little risk to livestock, but its association with sulfate represents a major concern, reason why the acceptable limits should be below $400 \mathrm{ppm}$, because values greater than $400 \mathrm{ppm}$ can have negative effect dependent on alkalinity and the pH of the water. Over $800 \mathrm{mg} /$ $\mathrm{dm}^{3}$ sodium can cause diarrhea and a drop in milk production in dairy cows (Tennis, 2007). High sodium levels in water may require adjustments to the amount of salt $(\mathrm{NaCl})$ added to dairy ration. Lack of drinking water sources and the negative repercussions resulting from the administration of water with high salt content, can be reduced by administration of betaine (Mavromichalis, 2013).

\section{Iron}

Weiss $(2008 ; 2010)$ claims that the although feed: hay, silage contains large amounts of iron, above $500 \mathrm{ppm}$ rarely causes adverse reactions because of insoluble form, ferric ion $\left(\mathrm{Fe}^{+3}\right)$, but, if the concentration is more than $0.3 \mathrm{ppm}$ in drinking water, this may cause problems for cows (www.positiveaction.info,) Amounts greater 
than $0.3 \mathrm{mg}$ iron $/ \mathrm{dm}^{3}$ induce an unpleasant taste of water, which leads to voluntary water consumption decrease concomitantly with the milk production (Swistock, 2012), but, the study performed by Mann et al., (2013) reveals the fact that iron intake up to $1.250 \mathrm{mg}$ per day for 14 days is safe for early lactation dairy cattle, not affect the chemical composition of milk but processed milk from those cows was susceptible to flavor changes.

Signs characteristic of chronic iron intoxication is manifested by reducing feed intake and feed conversion efficiency (Man, 2002). Excessive intake of iron in the water consumed of cattle, after Linn, (2008) has an adverse effect due to increasing the reactivity of oxidative species (oxidative stress) that harms the cell membranes and interrupt several biochemical reactions in the body.

Oxidative stress in cattle was incriminated in increased incidence of metritis and mastitis (Tomlinson, 2014) fetal membrane retention, decreases absorption of essential minerals, decreased immunity, increase the risk of infections and affected milk production.

Usually the adverse effects of iron are indirect through association with secondary deficiencies resulting from antagonistic action (Beede, 2006).

High iron, manganese, or molybdenum content may increase needs for copper (Broadwater, 2007), copper deficiency is in most cases an result from an excess of iron in the diet of dairy cows (Drăghici, 2001), but in the same time decrease absorption of manganese from the diet (Prairie et al., 2014), magnesium and calcium that lead to decrease in productive performance and health of cows. The iron in quantities greater than $0.3 \mathrm{mg} /$ $\mathrm{dm}^{3}$ has negative impact on absorption of and $\mathrm{Zn}$ (Stephen et al., 2008), therefore Higgins, (2008) considers that one of the critical analysis is the analysis of the level of iron in the water, because, ferrous iron $\left(\mathrm{Fe}^{2+}\right)$ dissolved in water is presumed to be highly absorbable with an estimated absorption rate approaching 100\%. After Linn, (2008) $\mathrm{pH}$ and the presence of sulfates from water plays decisive role on the form and solubility of iron. The less soluble ferric form $\left(\mathrm{Fe}^{+3}\right)$ combined with $\mathrm{OH}$ is found at $\mathrm{pH}$ values below7, and at a $\mathrm{pH}$ above 9.5 unit $\mathrm{pH}$ the greatest amount of iron can be found as ferric form combined with $\mathrm{OH}$. Water taste may be altered at values greater than 200 $\mathrm{ppm} / \mathrm{dm}^{3}$ sulfates present in the water when iron combines with them in a higher percentage than with $\mathrm{OH}$.

\section{Manganese}

Manganese belongs to the category non toxic substances whose origin can be telluric especially for groundwaters but like iron, at high levels can clog the water supply system (Braul et al., 2001) through formation of deposits visible in plumbing in filters and watering devices (Beede, 2006) having aspect by black slime almost like crude oil (Jim, 2008), that is why the amount of manganese is limited to $0.05 \mathrm{mg} / \mathrm{dm}^{3}$.

Beyond this range, manganese affects water intake due to the change in water taste, which leads to reducing livestock consumption (Provin et al., 2002), although ruminants appear to tolerate large quantities of ingested manganese. One reason is the absorption of manganese is much lower than other minerals (Linn, 2008).

\section{Nitrates and nitrites}

Nitrates from water can have telluric origin or result of contamination with nitrogenous fertilizers (Harty, 2012), fecaloid household waters or industrial (Hegedűs, 2006), shallow wells with poor casings are susceptible to contamination (Lardy et al., 2008). At adult cattle, nitrate toxicity is much lower compared to that of nitrites which are absorbed faster, being of 10 times more toxic than the nitrate (Hardy, 2012). Ruminal microorganisms are well equipped to break down nitrate to ammonia nitrogen (Mireșan, 2001), but high load of nitrate present in water at which is added the nitrate present in the feed, overburdens the ruminal microorganisms to decompose entirely nitrate into ammonia, increase intermediate forms, nitrite, being toxic for cellulolytic bacteria (www.animalscience.ucdvis.edu $u_{2}$ ). In this way is affected the efficiency of fiber digestibility in the rumen, decrease milk production and finally induce poisoning of the animals (Adams et al., 2012). The feed rich in nitrates accompanied by intake of water with high amount by nitrates leads in most cases at intoxications (Bedee, 2012).

The quantity of nitrates in plants is dependent of growth stage; weather conditions: low temperature, frost, hail, drought (www.uwyo. edu,).

Green plants such as: barley, wheat, rye, maize, sorghum, sudan grass, beet, rape, sweet clover, 
can accumulate large amounts of nitrate in these conditions (Likens , 2015), but quantity of nitrate can increase also because of improper storage of feed, in particular the oat hay surprised at rain or snow before use in animal ration (Robson , 2007).

National Research Council (N.R.C.),(2001) (profsite.um.ac.ir) stipulates that under 44 (0$44 \mathrm{ppm}$ ) $\mathrm{mg}$ nitrate $/ \mathrm{dm}^{3}$ equivalent to $0-10 \mathrm{mg}$ Nitrate Nitrogen $\left(\mathrm{NO}_{3}-\mathrm{N}\right) / \mathrm{dm}^{3} \quad\left[\left(10 \mathrm{mg} / \mathrm{dm}^{3}\right.\right.$ nitrate-nitrogen $\left(\mathrm{NO}_{3}-\mathrm{N}\right)=44.3 \mathrm{mg} / \mathrm{L}$ nitrate $\left(\mathrm{NO}_{3}\right)$ ] in water is safe for consumption by ruminants, generally safe between $45-123$ ppm $\mathrm{NO}_{3}$ (equivalent to $10-20 \mathrm{mg} / \mathrm{dm}^{3} \mathrm{NO}_{3}-\mathrm{N}$ ) on the condition that nitrates in forage content to be reduced (Tennis , 2007). Dyer (2012) consider that water containing less than 100 ppm is safe water, which certainly can be consumed by cows and between 100-300 ppm water quality is poor. Starting with $133 \mathrm{ppm}$ until $220 \mathrm{mg}$ nitrate $/ \mathrm{dm}^{3}$ (equivalent $20-40 \mathrm{mg} / \mathrm{dm}^{3} \mathrm{NO}_{3}-\mathrm{N}$ ) constitutes the beginning of problems related by deteriorating the health status of the animals (Beede , 2012). From the same source: National Research Council (N.R.C.), 2001 (profsite.um.ac.ir) between: 221 to $660 \mathrm{ppm} \mathrm{NO}_{3}$ (equivalent to $40-100 \mathrm{mg} / \mathrm{dm}^{3}$ $\mathrm{NO}_{3}-\mathrm{N}$ ) represents a risk and can cause even death. Over 660 ppm NO${ }_{3}$ (equivalent: over $100 \mathrm{mg} / \mathrm{dm}^{3}$ $\mathrm{NO}_{3}-\mathrm{N}$ ) represents a threshold unsafe for animals.

Nitrates have local irritant action on the digestive tract, causing congestion and hemorrhage (Drăghici, 2001). The process is influenced by the number and quality of microflora, $\mathrm{pH}$, temperature and level of nutrition, the nitrification being intensity at the $\mathrm{pH}$ of the water between 7-8 pH units and temperature $18-34^{\circ} \mathrm{C}$ (El Mahdy, 2013). By Adam et al., (2012), concentrations between $500 \mathrm{ppm}$ and $1.000 \mathrm{ppm}$ can produce symptoms of poisoning and over $1.000 \mathrm{ppm}$ is manifested in acute form causing the death of the animals.

Chronic toxicity causes lower performance (Dyer, 2012), decreased weight gain and milk production, increased susceptibility to infection (Higgins et al., 2008).

Moderate poisoning is manifested by vitamin deficiencies, conversion of carotenoids into vitamin A, anemia, poor health, infertility, abortion (Man, 2002). Prolonged exposure to excess nitrate coupled with cold stress and inadequate nutrition may lead to the alert downer cow syndrome (Thompson, 2014). In acute intoxication can be seen: difficulty breathing, rapid pulse, frothing at the mouth, convulsions, cyanosis of muzzle and the appearance of the bluish tints around the eyes (www.omafra.gov.on.ca,). Some minerals such as molybdenum, copper, iron, magnesium, and manganese are involved in the complete reduction of nitrate to ammonia, which avoids nitrite accumulation (Adams et al., 2012).

On reproduction and reproductive indices Linn (2008) cites the results of research performed by Kahler et al., (1974) which found that drinking water containing 86 ppm nitrate-nitrogen during the two years is not affecting the production or reproduction but after this period, was noticed decline of some reproductive indices such as: increased services per conception and longer calving interval. Ensley (2000) quoted by the same author observed slightly decline of reproduction performance at cows who drank water containing higher than 20 ppm nitrate-nitrogen.

Nitrite levels in water which are over 4 ppm may be toxic to cattle. Symptoms include infertility, reduced gains, abortions, respiratory distress and eventually death (Grant, 1993). Nitrites are highly toxic because pass through the rumen wall into the blood combines with the hemoglobin substitutes the oxygen and converted into methaemoglobinaemia, stable product losing capacity to cede the oxygen causing hypoxia in all tissues including fetal membrane (Warren, 2012), causing the incidence of spontaneous abortions. Symptomatology poisoning depends on percentage of methemoglobin. At $30-40 \%$ methemoglobinemia it can be notice: rapid, weak heartbeat with subnormal body temperature, muscular tremors, weakness and ataxia. At increasing the value of $50 \%$ mucous membranes are cyanotic and symptomatic manifestations are translated through: dyspnea, tachypnea, anxiety and frequent urination. Animal death occurs over 80\% methemoglobin (Thompson, 2014). Cattle will exhibit bizarre behavior, violent in which case the animal's status is getting worse due to higher oxygen requirements to support muscle activity. It is found relaxing effect on smooth muscle, especially on blood vessels, producing a true hemorrhage translated by peripheral collapse.

\section{Biological properties}

Excessive growth of the blue-green algae (cyanobacteria) in stagnant waters can lead to increasing the ingestion risk (Poppenga et al., 
2014). Some cyanobacteria are toxic, either by producing a neurotoxin in which case the death of animals is immediately, either by producing hepatotoxins which may cause death of the animals within a few hours to 2 days.

The clinical signs are noticed up after 15 minutes after ingestion (Braul et al., 2001), translated through weakness, photosensitivity, bloody diarrhea, tremors, convulsions and exitus (Judd, 2011). It can be observed photosensitization at animals who survive poisoning especially in non-pigmented areas (Salverson , 2012).

The most common species of cyanobacteria involved in animal poisoning: Microcystins, Anabaena, Planktothrix, Nostoc, Oscillatoria, and Anabaenopsis (Rumbeiha , 2015). Microcystins affects liver causing massive centrilobular hepatic necrosis and Anabaena, Planktothrix, Oscillaria, Microcystin species produce anatoxins, responsible for nervous system impairment beeing a nicotinic agonist at the cholinergic receptors but also as irreversible acetylcholinesterase inhibitor (Rumbeiha, 2015). Symptoms of poisoning are similar to those caused by ingestion of organophosphorus insecticides (El Mahdy, 2014). An indicator of blue green algae poisoning is the numerous dead rodents and other small animals near the water (Lardy et al., 2008).

\section{Microbiological properties}

Even if the water does not contain pathogens, existence of sick animals and using collective drinkers maintain the danger of disease transmission on hydric way (Drăghici , 2001). Hydric way is a tool of transmission of leptospirosis, important for the transmission of diseases caused by pathogens hydro telluric (anthrax, botulism, salmonellosis and some digestive virosis), having an accessory role in the transmission of parasites diseases of animals (Man, 1989; 2007).

Enteritis and enterocolitis are diseases that are part of the large group of diarrhoeal disease which continues to occupy a significant percentage in the pathology of digestive infectious. Faecal contamination of water lead to transmission: E.Coli, cryptosporidia, salmonella and leptospirosis (www.agr.gc.ca,). Leptospirosis. Survival in water is limited up to 2 weeks, depending on the environmental conditions (temperature, $\mathrm{pH}$ of the water or the chemical composition of water) (El Mahdy, 2013), causing increased rates of miscarriage, usually occurring between two to five weeks after the initial infection (www.agr. gc.ca,). Brucellosis (Brucella sp.), is a disease more common in animals. The agent is destroyed by ultraviolet radiation (El Mahdy, 2014). Tuberculosis, (Mycobacterium tuberculosis), can be isolate in surface waters polluted with wastewater (Hegedűs, 2006).

Many parasites are transmitted by water or, the water represents the environment for completion of the the biological cycle of the parasite (Man, 2002).

After Looper (2012) fecal coliforms is an indicator of feces pollution and fecal streptococci indicate the nature of pollution, animal or human. The percentage of these microorganisms indicates the type of pollution, animal or human. If fecal coliform bacteria have significantly higher percentage than fecal streptococci is suspected human source pollution, but if fecal streptococci exceed fecal coliform the pollution source is of animal origin. To ensure the integrity of status health in terms of bacteriological parameters, Grant (1993) assess water for animals as follows: safe water: total bacteria under 200/100 ml; less than $1 / 100 \mathrm{ml}$ at total coliform, fecal coliform and fecal streptococci. The number of bacteria that can cause health problems by drinking waters contaminated microbiolgic can occur at over $1.000000 / 100 \mathrm{ml}$ total bacteria at adult, although Broadwater (2007) considers that over 500/100 $\mathrm{ml}$ total bacteria counts may indicate water quality problems and the water with over 1.000000 total bacteria counts should be avoided as a source of water for cows.

Other indications of microbiological contamination of water consist of fecal coliform exceedances: over $1 / 100 \mathrm{ml}$ to calves and 15$50 / 100 \mathrm{ml}$ to cows, in which case can cause scours in calves and at adult count of $15-20 / 100 \mathrm{ml}$ can cause diarrhea and cows may go off-feed (Wright, 2014). After Looper (2012) total coliform should not exceed 15/100 $\mathrm{ml}$ and fecal coliform must be under $10 / 100 \mathrm{ml}$ to cows. Signs which indicate of microbiological contamination of water are put when fecal coliform exceeds $10 / 100 \mathrm{ml}$ to cows, $1 / 100 \mathrm{ml}$ to calves and the count of fecal streptococci are over $3 / 100 \mathrm{ml}$ to calves or over $30 / 100 \mathrm{ml}$ to adult cows. 


\section{CONCLUSION}

Alongside with minerals in the feed, the contribution of minerals in the water is essential. Ensuring water quality has as result maintained welfare, health, production and reproduction in dairy cows. Is required the regular testing the water quality administered to livestock, certain compounds that are found in excess having a negative impact, anti-nutritive and challenging of changes in the health status of the animals.

The presence of calcium in excess has negative repercussions on health, through installating of digestive and skeletal disorders, being closely related to increasing the hardness of water.

It is heady necessary to make laboratory analyses for both: food and water, regarding the biogenic elements based on nitrogen: nitrates, nitrites because excess leads to poisoning.

Reproductive sphere is especially affected by high amounts of iron present in water.

Water sources must be continuously monitored particularly in terms of microbiological parameters, because, the waterborne diseases affect all animals that consume from contaminated water.

It is preferred that, the watering to do from rivers, not from a stagnant water source whose quality it degrades and occurs blooming algae, with serious repercussions on health, especially by ingestion of blue green algae.

\section{REFERENCES}

1. Adams RS, McCarty TR, Hutchinson JL (2012). Prevention and Control of Nitrate Toxicity in Cattle, www.articles. extension.org

2. Adams RS, Sharpe WE (2009).Water intake and quality for dairy cattle.DAS 95-8, extension.psu.edu

3. Andersson M (1985). Effects of drinking water temperatures on water intake and milk yield of tied-up dairy cows Livestock Production Science. vol 12 (4):329. 338

4. Bagley CV, Kotuby AJ, Kitt FP (1997). Analysis of Water Quality for Livestock, digitalcommons.usu.edu

5. Beede DK (2005). The Most Essential Essential Nutrient: Water, Proc. Western Dairy Management Conf:1-22

6. Beede DK (2006). Evaluation of Water Quality and Nutrition for Dairy Cattle,Proc. High Plains Dairy Conf.,p. 129-153 www.puroxi.com

7. Beede DK (2012). Water nutrition and quality for dairy cattle, extension.missouri.edu

8. Beede DK (1994). Water: the most important nutrient for dairy cattle www.dairy.ifas.ufl.edu,
9. Bradford PS (2014). Large Animal Internal Medicine: 975 in Elsevier Science Health Science, www.books.google.ro,

10. Braul L, Kirychuk B (2001). Water qualiy and cattle. Importance of water quality to cattle. www.pfra.ca

11. Broadwater N (2007). What if cows don't drink enough water, www.extension.umn.edu

12. Brownson R, Zollinger B. Nitrates in cattle feed and water www.uwyo.edu

13. Crawford G (2012). Managing Sulfur Concentrations in Feed and Water, www.extension.umn.edu

14. Curran G (2014). Water for livestock: interpreting water quality tests.www.dpi.nsw.gov.au

15. Curran G, Robson S (2007). Water for livestock: interpreting water quality tests. PRIMEFACT 533:1- 5

16. Drăghici C (1996) Water hygiene and animal watering, p121-174.In: Animal hygiene and environmental. Ed Academicpres, Cluj- Napoca

17. Drăghici C (2001). Animal hygiene and environmental protection . Ed Risoprint, Cluj - Napoca

18. Dumitru M (1996).Nutrition and metabolism diseases in animals . Ed.Ceres, București

19. Dyer TG (2012). Water Requirements and Quality Issues for Cattle, Special Bulletin 56 extension.uga.edu

20. El Mahdy C (2013). Water hygiene and watering, p. 140-207.In: Zoo hygiene. Vol I "Natural environmental factors and influence on animal organism: beneficial and unfavorable action" ed. Napoca Star

21. El Mahdy C (2014). Noxious and professional diseases,p. 43-145.In: Ergonomics and work protection. General and special rules of labor protection in the livestock sector. Basic principles of ergonomics in work performed by students. Ed.Napoca Star

22. Elrod C (2013). Water for cows presented at Cornell Nutrition Conference www.waterforcows.com

23. Ensley SM (2000). „Relationships of drinking water quality to production and reproduction in dairy herds , Retrospective PhD Diss. Abstr.1-117, lib.driastate.edu

24. Gadberry S, Water For Beef Cattle, www.uaex.edu

25. German D, Thiex N, Wright C (2008). Interpretation of Water Analysis for Livestock Suitability www.agbiopubs. sdstate.edu

26. Gligor V, Ionescu D (1971) Hygiene livestock. Ed. Didactică şi Pedagogică, București

27. González Pereyra AV, Maldonado May V, Catracchia CG, Herrero MA, Flores MC, Mazzini M (2010). Influence of water temperature and heat stress on drinking water intake in dairy cows. Chilean Journal of Agricultural Research vol.70(2):328-336

28. Grant RJ (1993). "G93-1138 Water Quality and Requirements for Dairy Cattle" www.digitalcommons. unl.edu

29. Griffith C (1998). Water Quality for Livestock, www.noble. org

30. Harper F (2012). Water for horses. www.animalscience. ag.utk.edu/ 
31. Harty A (2012). High Sulfate Water Concerns for Livestock., www.igrow.org

32. Haydock D (2003).Sulfur-induced polioencephalomalacia in a herd of rotationally grazed beef cattle,www.ncbi.nlm. nih.gov

33. Hegedüs C (2006). Biodegradation and waste recycling. Practical work, ed. Academic Pres, Cluj Napoca

34. Hersom M, Crawford S (2008). Water Nutrition and Quality Considerations for Cattle. UFIFAS Extension; AN195., edis.ifas.ufl.edu

35. Higgins SF, Agouridis CT (2008). Drinking Water Quality Guidelines for Cattle, www2.ca.uky.edu

36. Hoehn RC (2002). Odor Production by Algae. Conference Workshop Presentation: Understanding and Controlling the Taste and Odor of Drinking Water. AWWA Annual Conference, New Orleans. www.trojanuv.com

37. Holter JB, Urban WE (1992). Water partitioning and intake prediction in dry and lactating Holstein cows. J. Dairy Sci. 75:1472-1479., extension.uga.edu

38. Hubbard WD (1907). Water-Works Management and Maintenance,www.archive.org : 307

39. Ionescu IA (1980). Algae. The proteins of the future. Ed. Ştiinţifică şi Enciclopedică, Bucureşti

40. Irsik M (2012). Water Quality for Livestock, www. extension.vetmed.ufl.edu

41. Ishle V. Water quantity and quality for dairy cattle www. didattica.unitus.it

42. Judd B (2011).Water Quality Testing for Horses, www. veterinarypartner.com

43. Kot-Wasik A (2007). Parameters of Natural Water. Water Quality Control www.pg.gda.pl

44. Lardy G, Stoltenow C, Johnson R (2008). Livestock and Water, www.ag.ndsu.nodak.edu

45. Likens J ( 2015). Nitrate toxicity, www.addl.purdue.edu

46. Linn JM, Knight R (2010). Water Quality and Quantity for Dairy Cattle, University of Minnesota, www.sheboygan. uwex.edu

47. Linn J (2008). Impact of minerals in water on dairy cows, www.extension.umn.edu

48. Benoni L (2011). The water.p 62-75.In: Zoo hygiene and Animal Welfare. Ed.Eurobit, Timișoara

49. Looper LM (2012). Quantity and Quality of Water for Dairy Cattle. www.uaex.edu

50. Looper LM, Waldner DN (2002). Water for Dairy Cattle, www.aces.nmsu.edu

51. Man C (1986). Water hygiene and watering, p. 89-143. In: Zoo hygiene. Course Tipo Agronomia, Cluj - Napoca

52. Man C (1989). Water - animal health and production. Ed. Ceres, București

53. Man C (2007). Ecological animal husbandry. Principles, techniques, regulations, case studies. Ed.Risoprint,ClujNapoca

54. Man C, Podar C, Ivan I (2002).Environmental artificial factors and their influence on cattle, 137-179. In: Ecology of cattle exploitation, Ed. AcademicPres,Cluj-Napoca
55. Mann G, Phetxumphou K, Gibson E, Martel C, Duncan S, Dietrich A, James R, Knowlton K(2013). Can iron in water affect milk production? www.progressivedairy.com

56. Mavromichalis I (2013). Six feed additives for pigs, poultry under heat stress. imavromichalis@wattnet.net

57. McFarland ML, Monty CD (2004). Drinking Water Problems: Iron and Manganese Texas Cooperative Extension, www.soiltesting.tamu.edu

58. Milos M, Drânceanu D (1980). Mineral nutrition of animals . Ed. Ceres, București

59. Mireşan V (2001). Endocrine physiology,p. 102-150. In: Physiology of domestic animals. Functions of relationship. Ed. AcademicPres, Cluj- Napoca Murphy M. R. 1992 Water metabolism of dairy cattle. J. Dairy Sci. vol.75: 326- 3330lkowski Andrew A. (2009). Livestock water quality a field guide for cattle, horses, poultry, and swine, www.agriculture.gov.sk.ca

60. Patterson T, Johnson P (2003). Effects of water quality on beef cattle. Proceedings, The Range Beef Cow Symposium XVIII, Mitchell, Nebraska, paper 63:1-9.

61. Pierce M (2011). Drinking water for dairy cattle: Part1. www.dairyherd.com

62. Podar C, Kelemen A, Reman DGh, Oroian I, Coloman S (2005). From the life and behavior of of cattle. Technological implications, Ed.Bucureşti, p.150

63. Popescu D (1985). Water hygiene and watering, p. 73-118. In: Livestock hygiene Ed. Ceres, București

64. Popescu D, Man C, Crăiniceanu E (1981). Zoo-hygiene and environmental protection. Ed. Did. și Ped., București

65. Popescu S (2010). Water hygiene and animals watering, p.97-162. In: Animal hygiene and environmental protection Partea I. Ed.Risoprint, Cluj- Napoca

66. Poppenga RH, Puschner B (2014). Drought-Related Poisoning and Nutritional Risks to Cattle, www.vetmed. ucdavis.edu

67. Prairie E, Tomlinson D (2014). Water quality and quantity critical to dairy cow performance, www.zinpro.com

68. Provin TL, Pitt JL (2012). Description of Water Analysis parameters, www.soiltesting.tamu.edu

69. Robson S (2007). Nitrate and Nitrite poisoning in livestock www.dpi.nsw.gov.au

70. Rumbeiha WK (2015). Blue green algae poisoning in cattle, www.msu.edu

71. Umar S, Tanveer MM, Azeem T, Shahzad A, Umar W, Rehman A, Ali SM (2014). Effects of Water Quality on Productivity and Performance of Livestock: A Mini Review. Journal Veterinaria Vol. 2 (2):11-15

72. Salverson R (2012). The Concern of Blue-Green Algae in Livestock Water http://igrow.org

73. Schlink AC, Nguyen ML, Viljoen GJ (2010). Water requirements for livestock production: a global perspective. Rev. sci. tech. Off. int. Epiz., vol.29 (3):603619

74. Schroeder JW (2015).Water Needs and Quality Guidelines for Dairy Cattle (AS1369) www.ag.ndsu.edu

75. Scrădeanu D, Alexandru Gh (2014). Natural factors of supply and groundwater regime, www.unibuc.ro 
76. Stockdale CR, King ${ }^{\mathrm{KR}}$ (1983). A note on some of the factors that affect the water consumption of lactating dairy cows at pasture Animal Science, Animal Science, vol.36:303

77. Straus H (1980). Diagnosis of potability of the water, p. 300-311.In: Hygiene. Ed Did si Pedagogica, Bucuresti

78. Swistock Bryan (2016). Interpreting drinking water tests for dairy cows, Water Facts,12, www.extension.psu.edu

79. Swistock BR (2012).Interpreting drinking water tests for dairy cows, www. extension.psu.edu

80. Swistock B, James (2012). Common Drinking Water Problems and Solutions, www.extension.psu.edu

81. Şara A (2007). Rational nutrition of farm animals. Ed. Risoprint, Cluj Napoca

82. Ștețca Gh, Hegedűs C (2008). Practical Guide for hygiene. Ed. Rissoprint, Cluj-Napoca

83. Tennis M (2007). Water Analysis Interpretation for Livestock. www.agriculture.alberta.ca

84. Teuşdea V (1996). Animal hygiene and animal protection vol.1. Ed Omega Lider, Bucureşti

85. Thompson LJ (2014). Overview of Nitrate and Nitrite Poisoning www.merckvetmanual.com

86. Tomlinson D (2014). Water quality and quantity is critical to dairy cow performance. International Dairy Topics .Vol. 14(1):13-15, www.positiveaction.info

87. Waldner D N, Michael LL (2012). Water for Dairy Cattle,www.extension.missouri.edu

88. Ward D, McKague K (2007). Water requirements of livestock, www.omafra.gov.on.ca

89. Warren R (2012). Nitrate Poisoning of Livestock Causes \& Prevention, igrow.org

90. Weiss WP (2008). Mineral Tolerances of Animals. www. agris.fao.org

91. Weiss WP (2010). Mineral Tolerances of Animals, articles. extension.org

92. Wright T (2003). Water Quality for Dairy Cattle www. omafra.gov.on.ca
93. Wright T (2012). Water Quality for Dairy Cattle, www. omafra.gov.on.ca

94. Iowa DNR Iowa Department of Natural Resources (2009). www.fwspubs.org

95. National Research Council (2000) The nutritional requirements of beef cattle. $7^{\text {th }}$ revised edition. Washington, D.C, www.nap.edu

96. National Research Council. (2001) Nutrient Requirements of Dairy Cattle: Seventh Revised Edition Chapter 8 Water requirement: 178-183, www.nap.edu

97. www. aidvet.com,2010,

98. www.agr.gc.ca, 2015

99. www.ediblegeography.com, 2011

100. www.ehsdata.com, 2000

101. www.epa.gov/dwstandardsregulations,2016

102. www.gov.ns.ca, 2008

103. www.holsteinfoundation.org, 2010

104. www.lenntech.com

105. www.positiveaction.info

106. www. animalscience.ucdavis.edu

107. www.milkproduction.com, 2000

108. www.milkproduction.com, 2007

109. www.milkproduction.com, 2011

110. www.omafra.gov.on.ca,1987

111. www.spiplastics.com

112. www.uaex.edu/publications

113. www.who.int, 2004

114. www.who.int, 2010

115. www2.gnb.ca, 2010 